\title{
Hydromechanical Behavior of Low-Swelling Soils Compacted at Low Water Content: Laboratory Study
}

\author{
Soumaïla Gandema1, Marcel Bawindsom Kébré ${ }^{1,2^{*}}{ }^{\mathbb{1}}$, Bétaboalé Naon ${ }^{1}$ \\ ${ }^{1}$ Laboratoire de Matériaux, d'Héliophysique et Environnement (LaMHE), Université Nazi-BONI, Bobo-Dioulasso, Burkina Faso \\ ${ }^{2}$ Laboratoire de Matériaux et Environnement (LAME), Université Joseph KI-ZERBO, Ouagadougou, Burkina Faso \\ Email: mkebre@gmail.com
}

How to cite this paper: Gandema, S., Kébré, M.B. and Naon, B. (2020) Hydromechanical Behavior of Low-Swelling Soils Compacted at Low Water Content: Laboratory Study. Engineering, 12, 824-838. https://doi.org/10.4236/eng.2020.1211058

Received: October 8, 2020

Accepted: November 27, 2020

Published: November 30, 2020

Copyright (๑) 2020 by author(s) and Scientific Research Publishing Inc. This work is licensed under the Creative Commons Attribution International License (CC BY 4.0).

http://creativecommons.org/licenses/by/4.0/ (c) (i) Open Access

\begin{abstract}
Fine unsaturated soils are used in many applications, particularly in road infrastructure and in construction. These materials undergo deformations according to the stresses to which they are subjected. The purpose of this paper is to study the influence of hydromechanical stresses on the behavior of low swelling soils compacted at low water content in accordance with the French standard GTR 92 (Guide des Terrassements Routiers). Then, various experimental tests on an oedometer were carried out in the laboratory. Two types of low swelling soil sampled in Nasso on the outskirts of the town of Bobo Dioulasso (Burkina Faso) were used. After shuffling, each sample was moistened to its optimum water content and then compacted to $90 \%$ and $95 \%$ of its optimum density. Behavior tests show that these soils deform very little when subjected to hydromechanical stresses. However, these deformations are swelling in nature for low mechanical stresses and when the stresses are high, they tend to collapse. When these soils are subjected to a vertical stress of 420 $\mathrm{kPa}$, the primary consolidation time is of the order of one minute for $\mathrm{NH} 2$ (a silty soil) and about ten minutes for $\mathrm{NH} 3$ (a silty-clayed soil).
\end{abstract}

\section{Keywords}

Unsaturated Soil, Compacted, Swelling, Low Water Content, Wetting, Oedometer, Hydro-Mechanical Behavior

\section{Introduction}

Resorting to the reuse of local soils, which are generally fine, in earthen structures (transport infrastructure embankments, in particular) is today an environmental necessity that meets the requirements of sustainable development. After being placed in backfill, these soils, initially unsaturated, can be subjected 
to water stress, in addition to their own weight, due to climatic conditions (floods and droughts) and/or human activities (excessive irrigation, water leaks, water pipes, etc.). These stresses can lead to major changes in the hydromechanical properties that could jeopardize the stability of structures.

However, a structure must be designed while ensuring its stability and durability. For this, its development must begin with the search for its location in nature and its most rational adaptation to the configuration of the land. Soils, load-bearing structures, must have satisfactory mechanical and physical characteristics. Indeed, they must withstand natural stresses and various human activities for several years, stresses leading to deformations.

To ensure the stability of the infrastructures of which they are the support, it is essential to know these deformations and the parameters which are associated with them and to take them into account in the dimensioning of the structure. Consequently, before any use, it is judicious to proceed to an identification of the type of soil to be made and of these possible deformations according to the stresses to which it will be subjected.

Understanding the behavior of soils and structures and their interactions therefore plays a growing and important role in geotechnical studies [1]. Therefore, since the early 1990s, the mechanics of unsaturated soils has been the subject of much research. Indeed, applications related to soil unsaturation affect practically all branches of geotechnics: volume variations due to shrinkage-swelling, environmental geotechnics, compacted structures such as road embankments and earth dams [2].

Several studies have been carried out in Burkina Faso or in the Sahelian zones on the basic materials used for road infrastructure. However, this work focuses more on geotechnical and physico-chemical properties of soils and treatment methods for use on pavements [3]. Litho-stabilization is one of these treatment methods and it consists of improving the lift or resistance of basic soil used as a foundation layer by adding a quantity of crushed with well-defined particle size characteristics. These methods are an improvement in the texture of the soil without seeking to understand the hydrodynamic behavior of the base material when it is subjected to varying loads.

It is in this context that our study is positioned, which aims to carry out humidification and consolidation tests in the laboratory on low swelling soils samples from western Burkina Faso. The objective is to study the hydromechanical behavior of low-swelling soils compacted at low water content.

After a brief overview of the study materials and methods, we will present the results on the hydric and physical characteristics of the soils as well as the results of the humidification and consolidation tests, which will be discussed.

\section{Materials and Methods}

\subsection{Physical and Morphological Characteristics of the Soils Samples}

\subsubsection{Localization and Extraction}

Soil samples were taken on the site of the Nazi-Boni University of Bobo Dio- 
ulasso (Nasso site) located about fifteen kilometers west of Bobo Dioulasso in a humid tropical climate zone. On the site, an excavation with a depth of $1 \mathrm{~m}$ over an area of $2.5 \mathrm{~m} \times 2 \mathrm{~m}$ was carried out. In view of the vertical stratification, three distinct layers were identified (Figure 1). Soil stocks were built up for each layer [4]. We will use the following names depending on the depth:

- $\mathrm{NH1}$, the surface layer or plant layer, from 0 to $30 \mathrm{~cm}$;

- $\mathrm{NH} 2$, the intermediate layer from 30 to $70 \mathrm{~cm}$ and

- $\mathrm{NH} 3$, the last deep beyond $70 \mathrm{~cm}$.

In this present study, we will use the $\mathrm{NH} 2$ and $\mathrm{NH} 3$ samples which have a clay content visibly higher than that of the NH1 surface layer. The physical and hydric characteristics of these two soils are therefore presented in the following.

\subsubsection{Physical and Morphological Characteristics}

The physical characterization of the studied soils consists in identifying them by the various geotechnical parameters. These parameters were determined by Kébré (2013) [4]. Table 1 summarizes the physical characteristics of the soils under study.

The morphological characterization consisted in the study of the grain size distribution of soils, by sieving (standard NF P 94 - 056) and by sedimentometry (standard NF P 94 - 057). On the other hand, mathematical models proposed in the literature to obtain this curve, that of Fredlund et al., (2000) [5] was used [4].

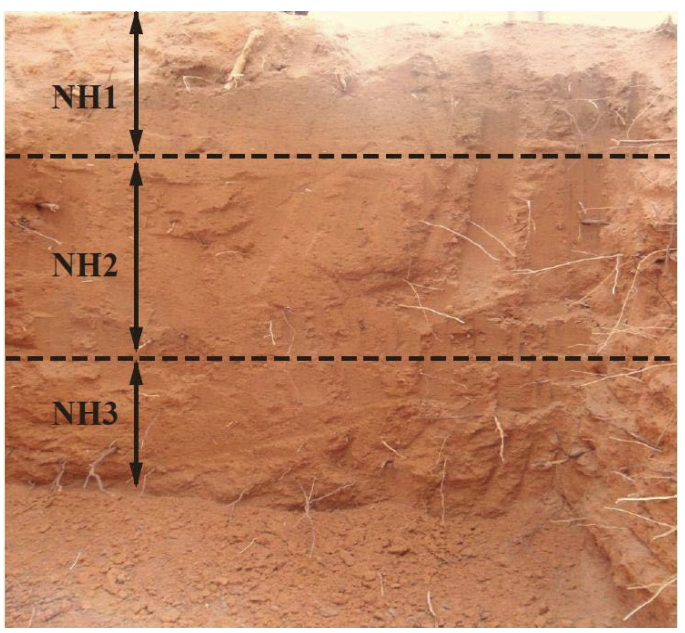

Figure 1. Vertical profile of the Nasso soil and definition of the $\mathrm{NH} 1, \mathrm{NH} 2$ and $\mathrm{NH} 3$ layers [4].

Table 1. Physical properties of soils under study [4].

\begin{tabular}{ccccccc}
\hline & $\rho_{d}$ & $n$ & $e$ & $w_{\text {SPO }}$ & $\rho_{\text {d-SPO }}$ & $w_{\text {sat }}$ \\
\cline { 2 - 7 } & $\left(\mathrm{kg} \cdot \mathrm{m}^{-3}\right)$ & - & - & $\left(\mathrm{kg} \cdot \mathrm{kg}^{-1}\right)$ & $\left(\mathrm{kg} \cdot \mathrm{m}^{-3}\right)$ & $\left(\mathrm{kg} \cdot \mathrm{kg}^{-1}\right)$ \\
\hline $\mathrm{NH} 2$ & 1652 & 0.37 & 0.60 & 0.092 & 1960 & 0.227 \\
$\mathrm{NH} 3$ & 1605 & 0.39 & 0.65 & 0.146 & 1790 & 0.245 \\
\hline
\end{tabular}

Note: $\rho_{d}=$ dry density; $n=$ porosity; $e=$ void ratio; $w_{S P O}=$ water content at standard Proctor optimum; $\rho_{\text {d-SPO }}=$ dry density at standard Proctor optimum; $w_{\text {sat }}=$ saturation water content. 
Figure 2 gives the grain size distribution curves obtained experimentally and by modelling. Table 2 presents the morphological characteristics of the soils as well as the texture in the USDA (United States Department of Agriculture) classification.

Figure 3 shows the normal Proctor curves for the NH2 (Figure 3(a)) and NH3 (Figure $3(b)$ ) samples. The characteristics are determined from the Proctor Normal test according to NF P 94 - 093.

\subsubsection{Soil Water Characteristic Curves}

Classical experimental devices were used to acquire data to characterize the soil water retention of the two sandy soil samples: 1) pressure plate apparatus at constant temperature $\left(30^{\circ} \mathrm{C}\right)$ for large water contents that correspond to the funicular state and 2) saturated salt solutions for small water contents in the hygroscopic state. For both methods, at equilibrium, gravimetric water content, $w$,

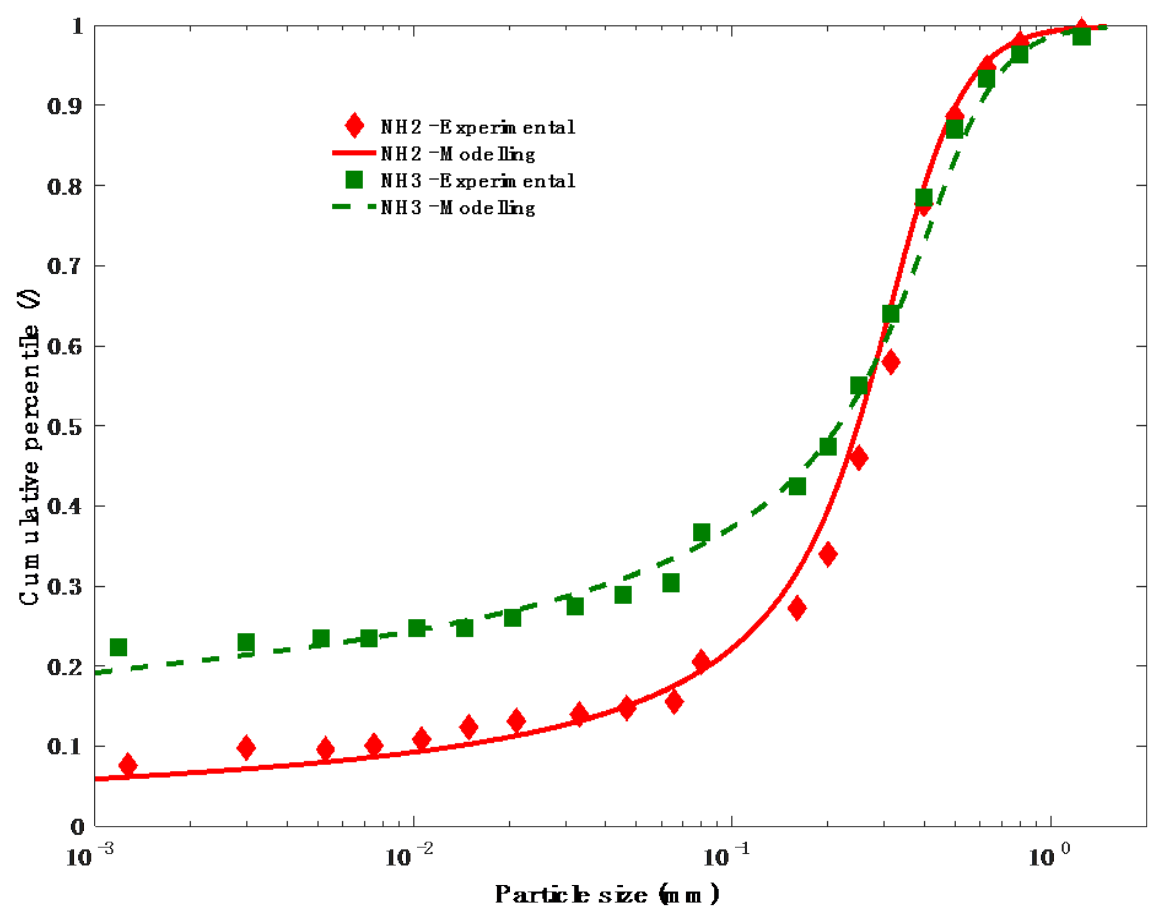

Figure 2. Soil granulometric curves for soil samples $\mathrm{NH} 2$ and NH3: measured (markers) and modeling (line) by [4].
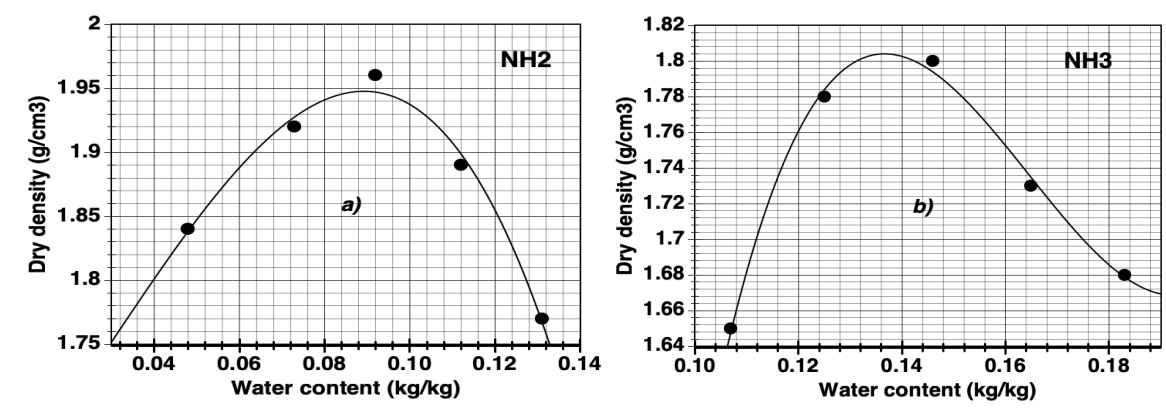

Figure 3. Normal proctor curves for $\mathrm{NH} 2$ and NH3 soils. 
Table 2. Morphological characteristics of soils [4].

\begin{tabular}{|c|c|c|c|c|c|c|}
\hline & \multicolumn{3}{|c|}{ Particle Class Proportions } & \multirow{3}{*}{$\begin{array}{c}\text { USDA } \\
\text { textural class }\end{array}$} & \multicolumn{2}{|c|}{ Curve parameters } \\
\hline & $\%$ Sand & $\%$ Silt & $\%$ Clay & & $C_{u}$ & $C_{c}$ \\
\hline$d(\mu \mathrm{m})$ & $d \geq 5$ & $2 \leq d<5$ & $d<2$ & & $\frac{d_{60}}{d_{10}}$ & $\frac{\left(d_{30}\right)^{2}}{d_{10} \times d_{60}}$ \\
\hline $\mathrm{NH} 2$ & 84.5 & 08.7 & 06.8 & Silty sand & 28.51 & 7.33 \\
\hline NH3 & 64.4 & 08.5 & 23.1 & Sandy-clay silt & 1625.96 & 24.50 \\
\hline
\end{tabular}

Note: $d=$ particle average diameter; $d_{x}$ represents the diameter of grains corresponding to $\mathrm{x} \%$ of cumulative sieves (passers); $C_{u}=$ coefficient of uniformity (Hagen); $C_{c}=$ coefficient of curvature.

was determined by weighing after oven-drying at $105^{\circ} \mathrm{C}$ for 48 hours [4]. The results and a discussion about water retention function modelling, especially at small water contents, are presented in Kébré et al., (2013) [6] and Kébré et al., (2017) [7].

The models of van Genuchten (1980) (Equation (1)) and Durner (1994) (Equation (2)) have been used to predict the soil characteristic curves $(s=f(w))$ of $\mathrm{NH} 2$ and $\mathrm{NH} 3$ samples respectively.

$$
\begin{gathered}
S_{r}=\frac{w-w_{r}}{w_{\text {sat }}-w_{r}}=\frac{1}{\left[1+(\alpha s)^{n}\right]^{m}} \\
S_{r}=\frac{w-w_{r}}{w_{\text {sat }}-w_{r}}=\sum_{i=1}^{k} \frac{\omega_{i}}{\left[1+(\alpha s)^{n_{i}}\right]^{m_{i}}}
\end{gathered}
$$

where $w_{r}\left(\mathrm{~kg} \cdot \mathrm{kg}^{-1}\right), \alpha\left(\mathrm{kPa}^{-1}\right), n(/)$ and $m(/)$ are fitting parameters. The integer $k$ denotes the soil modality and $\omega_{i}$ is a weighting factor for the portions of curves with the following conditions: $0<\omega_{i}<1$ and $\sum \omega_{i}=1$.

The values of the coefficients of Equations (1)-(2) are given in Table 3 and Table 4 for NH2 and NH3 soils samples. The values of statistical parameters determining the performance of the models in representing the experimental values as the coefficient of determination, $\mathrm{R}^{2}$, and standard deviation, RMSE (Root Mean Square Error), are recorded in this table. The corresponding soil water characteristic curves are represented in Figure 4(a) and Figure 4(b).

Because we aim to predict the hydromechanical behavior of these soils compacted at low water content behavior, the concept of residual water content is meaningless and we assume $w_{r}=0$ in Equations (1) and (2). Globally, a good agreement between experimental and predicted data is achieved with the two models. These curves allow to know the water content of soil for any value of the intrinsic stress in the soil corresponding to the suction.

From soil water characteristic curves (SWCC), it noticed that the case of NH3 soil is particular. The characteristic curve of NH3 has two steps corresponding to double porosity environments also called bimodal porous environments [4] [8]. Moreover, the slop of NH2 SWCC is more pronounced than that of $\mathrm{NH} 3$ at higher suction corresponding to low water content. 
Table 3. Evaluation of parameter values from Equations (1) forNH2 soil water characteristic curve with the statistics $\mathrm{R}^{2}$ and root mean square error (RMSE) for the accuracy of prediction.

\begin{tabular}{ccccc}
\hline & Parameters & \multicolumn{3}{c}{ Statistics } \\
\hline$\alpha$ & $n$ & $M$ & $\mathrm{R}^{2}$ & $\mathrm{RMSE}$ \\
\hline $\mathrm{k} \cdot \mathrm{Pa}^{-1}$ & & & $\%$ & $\mathrm{~kg} \cdot \mathrm{kg}^{-1}$ \\
\hline 1.902 & 6.736 & 0.0426 & 99.52 & 0.0052 \\
\hline
\end{tabular}

Table 4. Evaluation of parameter values from Equations (2) for NH3 soil water characteristic curve with the statistics $\mathrm{R}^{2}$ and root mean square error (RMSE) for the accuracy of prediction.

\begin{tabular}{ccccccccc}
\hline \multicolumn{9}{c}{ Parameters } \\
\hline$\omega_{1}$ & $\alpha_{1}$ & $n_{1}$ & $m_{1}$ & $\alpha_{2}$ & $n_{2}$ & $m_{2}$ & $\mathrm{R}^{2}$ & \multicolumn{2}{c}{$\mathrm{RMSE}$} \\
\hline- & ${\mathrm{k} \cdot \mathrm{Pa}^{-1}}^{-1}$ & - & - & ${\mathrm{k} \cdot \mathrm{Pa}^{-1}}^{-1}$ & - & - & $\%$ & $\mathrm{~kg} \cdot \mathrm{kg}^{-1}$ \\
0.66 & $1.10 \times 10^{-4}$ & 1.320 & 1.012 & 0.407 & 21.247 & 0.052 & 99.98 & 0.0006 \\
\hline
\end{tabular}
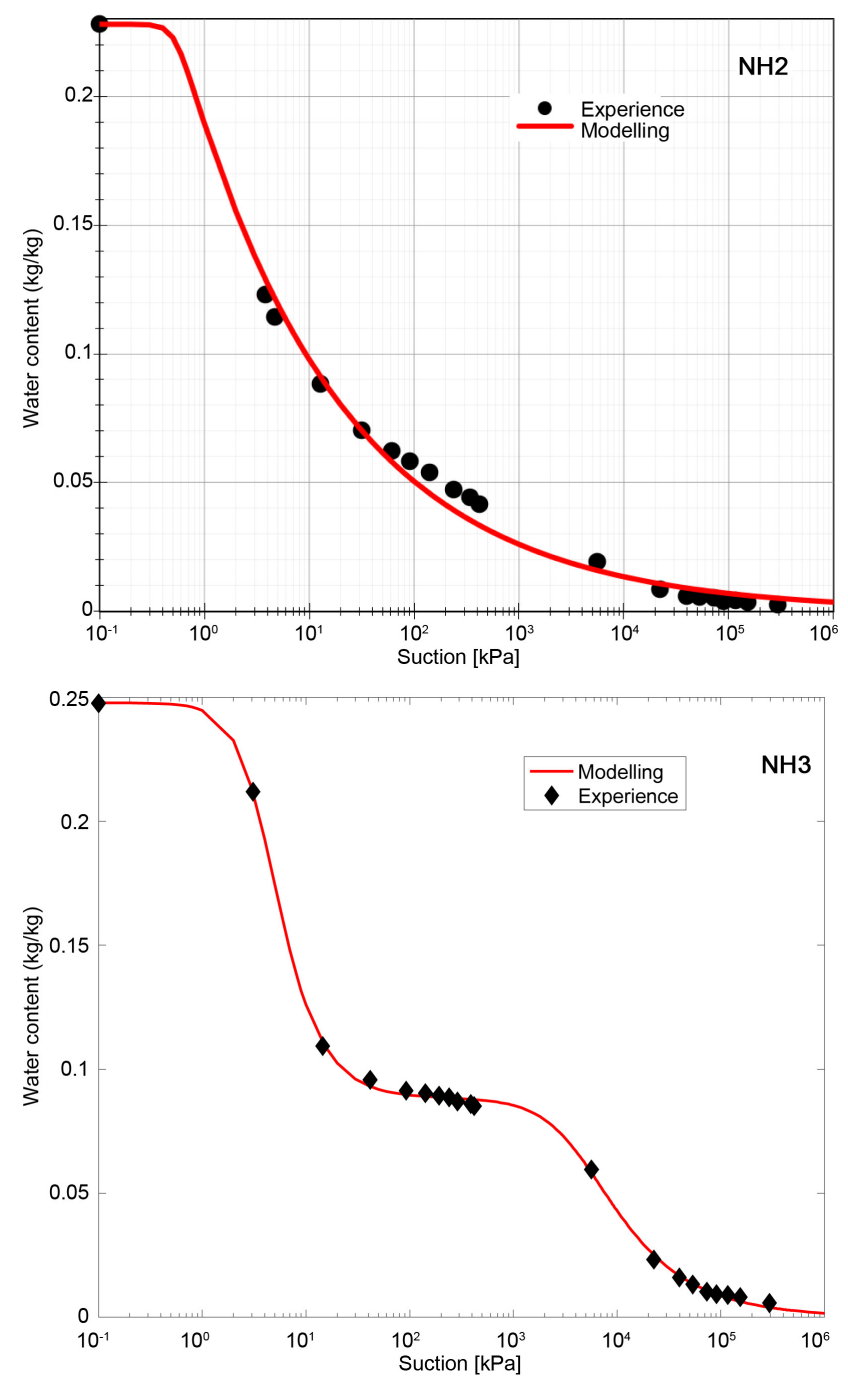

Figure 4. Soil water characteristic curves of $\mathrm{NH} 2$ and $\mathrm{NH} 3$. 


\subsection{Wetting and Consolidation Tests}

Many tests are available to evaluate the evolution of the voids ratio over time. Among these, we can cite: stress wetting tests, Huder-Amberg swelling test, standardized and non-standardized oedometric tests [9]. Our choice fell on the stress wetting method for several compaction conditions at low water content. We describe the experimental protocol that we implemented in the laboratory to evaluate the hydromechanical behavior of these soils.

\subsubsection{Samples Preparation}

Each soil sample is first passed through a $2 \mathrm{~mm}$ sieve and then oven-dried. After cooling in ambient air, it has been humidified to its optimum water content $w_{O P N}$ and placed in an airtight chamber for 24 hours for good homogenization. With these wet soils, compaction is done following the Proctor Normal test. Each soil is compacted at $90 \%$ and $95 \%$ of its optimum dry density $\rho_{\text {dopN }}$. Using oedometric molds (Figure 5) with dimensions $D_{0}=50 \mathrm{~mm}$ and $H_{0}=20 \mathrm{~mm}$, test pieces (Figure 5) are taken from the samples obtained during the previous compaction.

Table 5 summarizes the characteristics of the four (4) test pieces of each soil used for the wetting tests and Table 6 for consolidation.

\subsubsection{Implementation of Tests}

The wetting test consists of subjecting the test pieces to first mechanical stress in undrained conditions for 24 hours (sufficient time to obtain a steady-state deformation). The soil sample has then been imbibited until the strain at equilibrium corresponding to saturation. From imbibition, the void ratio in the test piece has been recorded at any times from equation:

$$
e(t)=\frac{h(t)-h_{p}}{h_{p}}
$$

$h(t)$ is the height of the test piece at given date $t$ and $h_{p}$, the equivalent solid height given by:

$$
h_{p}=\frac{W_{d}}{\gamma_{s} \times S}
$$
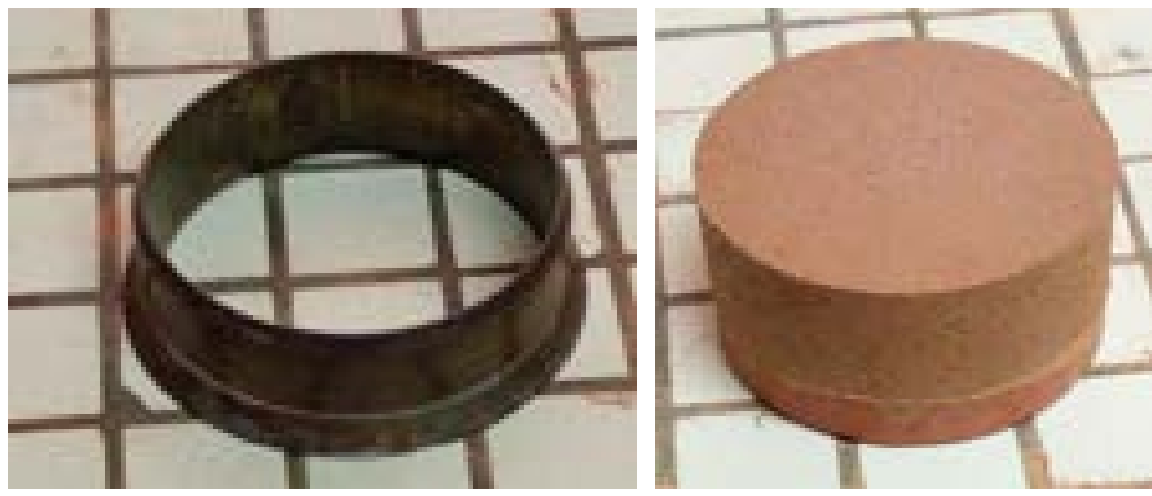

Figure 5. An Oedometric molds and a test piece. 
Table 5. Characteristics of $\mathrm{NH} 2$ and $\mathrm{NH} 3$ test pieces.

\begin{tabular}{ccccc}
\hline Void ratio & $\begin{array}{c}\text { Degree of } \\
\text { saturation }\end{array}$ & Dry density & Dry mass & $\begin{array}{c}\text { Vertical } \\
\text { stress }\end{array}$ \\
\hline$e_{0}(/)$ & $S_{r}(\%)$ & $\rho_{d}\left(\mathrm{~kg} \cdot \mathrm{m}^{-3}\right)$ & $m_{s}=\rho_{d} V_{0}(\mathrm{~g})$ & $\sigma_{v}(\mathrm{kPa})$ \\
\hline 0.375 & & $\mathrm{NH2}$ & & \\
0.317 & 66.08 & 1764 & 75.36 & 36 \\
0.320 & 72.97 & 1764 & 77.36 & 420 \\
0.300 & 76.99 & 1862 & 78.45 & 36 \\
\hline 0.376 & 76.06 & 1862 & 78.20 & 420 \\
0.311 & 97.04 & $\mathrm{NH3}$ & & \\
0.400 & 97.76 & 1611 & 74.06 & 36 \\
0.287 & 93.35 & 1611 & 74.22 & 420 \\
\hline
\end{tabular}

Table 6. Characteristics of consolidation test pieces.

\begin{tabular}{cccccc}
\hline $\begin{array}{c}\text { Instant } \\
\text { settlement }\end{array}$ & $\begin{array}{c}\text { Water } \\
\text { content }\end{array}$ & Void ratio & $\begin{array}{c}\text { Degree of } \\
\text { Saturation }\end{array}$ & Dry density & Dry mass \\
\hline$\Delta h_{i}(\mathrm{~mm})$ & $w_{0}\left(\mathrm{~kg} \cdot \mathrm{kg}^{-1}\right)$ & $e_{0}(/)$ & $S_{r}(\%)$ & $\rho_{d}\left(\mathrm{~kg} \cdot \mathrm{m}^{-3}\right)$ & $m_{s}=\rho_{d} V_{0}(\mathrm{~g})$ \\
\hline 1.2 & 0.1030 & 0.38 & 75.81 & 1862 & 75.68 \\
1.5 & 0.1505 & 0.43 & 93.01 & 1700.5 & 72.84 \\
\hline
\end{tabular}

where $W_{d}$ is the weight of dry soil, $S$ the straight section of the test piece, $\gamma_{s}$ the volume weight of grains taken at $\gamma_{s}=26.5 \mathrm{kN} / \mathrm{m}^{3} \quad$ [10].

The void ratio $e_{0}$ at equilibrium is given by:

$$
e_{0}=\frac{h_{0}-h_{p}}{h_{p}}
$$

with $h_{0}$ the height of the test piece at steady state.

As for the consolidation tests, this involves subjecting the test piece contained in the oedometric mold to vertical pressure using a piston and then record its height at specific times. This test is carried out on a saturated sample.

The minimum value of the settlement axis corresponds to the deformation $d_{0}$ associated with the initial deformation corrected at the beginning of loading. To determine this deformation $d_{0}$, two points of the curve are selected, $\left(d_{1}, t_{1}\right)$ and $\left(d_{2}, t_{2}\right)$ with:

$$
t_{2}=4 \times t_{1}
$$

The deformation $d_{0}$ is then given by:

$$
d_{0}=d_{1}-\left(d_{2}-d_{1}\right)
$$

The coefficient of consolidation $C_{v}$ is calculated from:

$$
C_{v}=\frac{0.197 \times h^{2}}{4 \times t_{50}}
$$


where $h$ is the thickness of the sample and $t_{50}$, the time required to obtain a settling at $50 \%$ of the primary consolidation.

For the determination of $t_{50}$, the settlement $\Delta h_{(U=100 \%)}$ obtained at the end of primary consolidation is first determined. $\Delta h_{(U=100 \%)}$ corresponds to the ordinate of the intersection point between the tangent to the settlement curve at the inflection point and the tangent at the end of the curve. The final primary consolidation settling time $t_{100}$ corresponds to the abscissa of this point. $\Delta h_{(U=50 \%)}$ corresponding to the $50 \%$ settling of the primary consolidation is half of $\Delta h_{(U=100 \%)}$ and has the abscissa $t_{50}$, this value is used to calculate $C_{v}$. For a $50 \%$ consolidation, the value of the time factor is $T_{V}=0.197$.

For each test, we also determine the oedometric modulus $E_{\text {oed }}$ (from Equation (9)) and the vertical permeability coefficient $k_{v}$ (from Equation (10)) of the soils [11]:

$$
E_{\text {oed }}=\frac{\Delta \sigma^{\prime}}{\Delta h_{100} / h_{0}}
$$

where $\Delta \sigma^{\prime}$ is the increment stress during loading: $\Delta \sigma^{\prime}=420 \mathrm{kPa}$

$$
k_{v}=\frac{C_{v} \gamma_{w}}{E_{o e d}}
$$

with $\gamma_{w}=10 \mathrm{kN} \cdot \mathrm{m}^{-3}$ the volume weight of water.

At the end of the tests carried out, data was collected and processed to get the results presented and discussed in next section.

\section{Results and Discussion}

\subsection{Wetting Tests}

Figure 6 and Figure 7 respectively for the NH2 and NH3 soils, show the evolution over time of the void ratio during the wetting of two identical test pieces subjected to different vertical stresses $\sigma_{V}$ (36 and $420 \mathrm{kPa}$ )

Through the results presented in Figure 6 and Figure 7, we note that the soils under study, which don't have high clayey rate, are very slightly deformable because of very small values of swelling potentials given in Table 7; the NH3 clay soil being more deformable than the $\mathrm{NH} 2$ soil. Swelling potential is the ratio between the variation in height of the test pieceafter wetting and its initial height.

We also distinguish, through these results, two types of behavior following imbibition [11] [12]:

- a swelling for low stresses ( $\left.\sigma_{v}=36 \mathrm{kPa}\right)$;

- a collapse for high stresses ( $\left.\sigma_{v}=420 \mathrm{kPa}\right)$.

In addition, as dry density increases, swelling decreases at low stresses based on the swelling potential (Table 7). Collapse also decreases at high stresses for the $\mathrm{NH} 3$ clay layer. For silty sand $\mathrm{NH} 2$, collapse is faster at high stresses $\left(\sigma_{v}=420 \mathrm{kPa}\right)$ than at low stresses $\left(\sigma_{v}=36 \mathrm{kPa}\right)$.

For a soil, there is a vertical transition stress $\sigma_{v t}$ between swelling and collapse. 


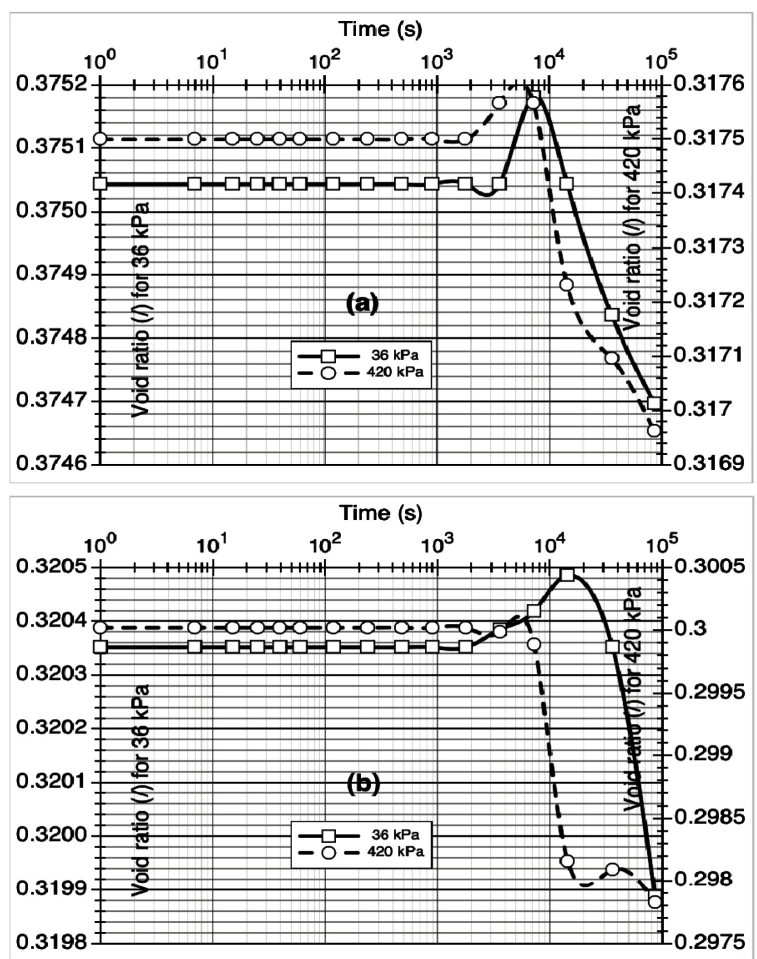

Figure 6. Evolution of void ratio of $\mathrm{NH} 2$ during wetting test at different vertical stresses: (a) $\rho_{d}=1764 \mathrm{~kg} \cdot \mathrm{m}^{-3}$; (b) $\rho_{d}=1862 \mathrm{~kg} \cdot \mathrm{m}^{-3}$.

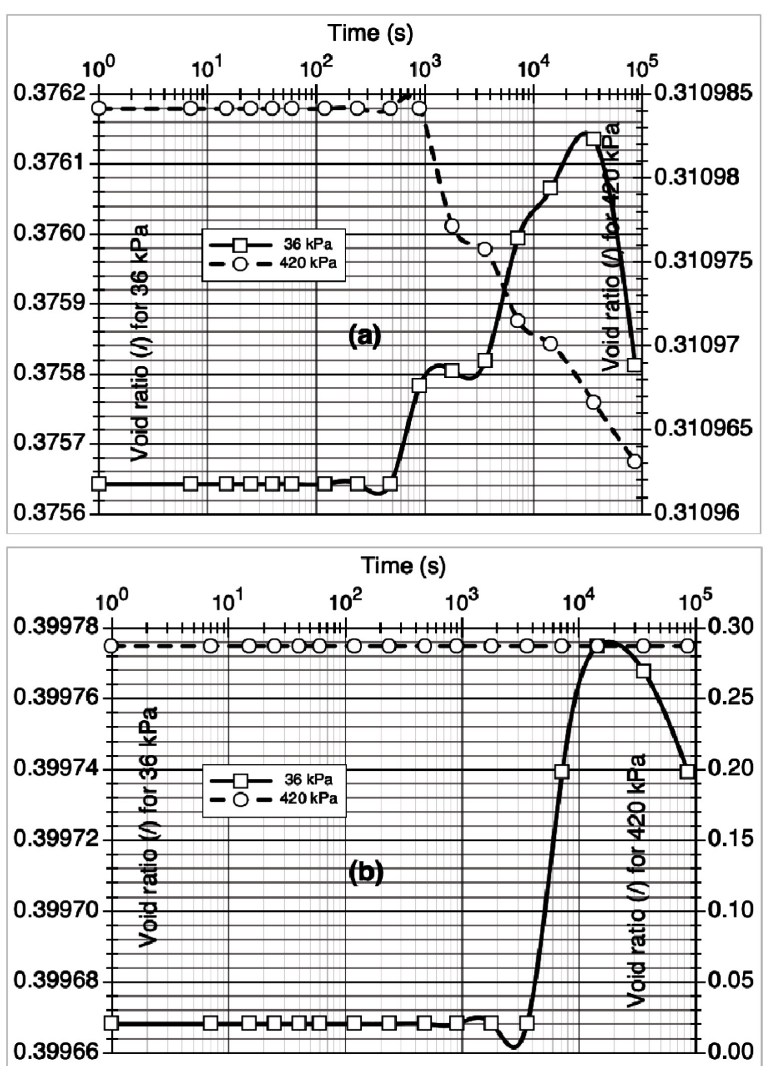

Figure 7. Evolution of void ratio of $\mathrm{NH} 3$ during wetting at different vertical stresses: (a) $\rho_{d}=1611 \mathrm{~kg} \cdot \mathrm{m}^{-3}$; (b) $\rho_{d}=1700.5 \mathrm{~kg} \cdot \mathrm{m}^{-3}$. 
Table 7. Swelling potentials of test pieces for the values of stresses applied for experimental tests.

\begin{tabular}{|c|c|c|c|c|c|}
\hline \multirow[b]{2}{*}{ Dry density } & \multirow[b]{2}{*}{$\left(\mathrm{kg} / \mathrm{m}^{3}\right)$} & \multicolumn{2}{|c|}{$\mathrm{NH} 2$} & \multicolumn{2}{|c|}{ NH3 } \\
\hline & & 1764 & 1862 & 1611 & 1700.5 \\
\hline $\begin{array}{l}\text { Swelling } \\
\text { potential }\end{array}$ & $\sigma_{v}=36 \mathrm{kPa}$ & $-2.5 \times 10^{-4}$ & $-3.5 \times 10^{-4}$ & $1.2 \times 10^{-4}$ & $5.08 \times 10^{-5}$ \\
\hline$C_{g}=\frac{h-h_{0}}{h_{0}}$ & $\sigma_{v}=420 \mathrm{kPa}$ & $-1.69 \times 10^{-3}$ & $-1.69 \times 10^{-3}$ & $-1.6 \times 10^{-5}$ & 0 \\
\hline
\end{tabular}

Results for our soils under study are showed in Figure 8 and Figure 9 and values in Table 8.

Figure 7 and Figure 8 show that the vertical transition stresses for the NH2 layer compacted at $90 \%$ and $95 \%$ are less than $36 \mathrm{kPa}$ while for the $\mathrm{NH} 3$ layer compacted at $90 \%$, the vertical transition stress is between 36 and $420 \mathrm{kPa}$. Figure 7(b) and Figure 9(b) show that the vertical transition stress for the NH3 layer compacted at $95 \%$ is exactly $420 \mathrm{kPa}$.

From the results obtained, we conclude that the vertical transition stress increases with the compaction rate. On the other hand, it evolves in the opposite direction with the initial void ratio.

\subsection{Consolidation Tests}

Figure 10 and Figure 11 show the consolidation curves of the studied materials.

Table 9 summarizes the consolidation characteristics and parameters $E_{\text {oed }}$ and $k_{v}$ of the studied soils.

According to Table 9, the NH2 layer, a silty soil, has a consolidation rate between $10^{-7} \mathrm{~m}^{2} \cdot \mathrm{s}^{-1}$ and $5 \times 10^{-6} \mathrm{~m}^{2} \cdot \mathrm{s}^{-1}$ and the NH3 layer is between $2 \times 10^{-8} \mathrm{~m}^{2} \cdot \mathrm{s}^{-1}$ and $4 \times 10^{-7} \mathrm{~m}^{2} \cdot \mathrm{s}^{-1}$. From the values of $t_{100}$, it is clear that NH3 consolidates much faster than $\mathrm{NH} 2$.

The values of $E_{\text {oed }}$ and $k_{v}$ obtained for $\mathrm{NH} 2$ are within the usual limits of the oedometric modulus and vertical permeability coefficient of a silty soil, i.e. between 3 and 35 and between $10^{-5}$ and $10^{-8}$ [12]. It is the same than NH3 soil which can be classified among silty, clay soils $\left(1<C_{v}<10 ; k_{v} \cong 10^{-8} \mathrm{~m} \cdot \mathrm{s}^{-1}\right)$ [13].

\section{Conclusions}

In this paper, hydro-mechanical and physical properties of low swelling soils $\mathrm{NH} 2$ and $\mathrm{NH} 3$ have been characterized. When they are subjected to hydro-mechanical stresses, they both tend to swell at low stresses and to collapse when the applied stress exceeds a certain value called transition stress. The sandier NH2 layer consolidates much faster than the clayey NH3 layer.

These results have been obtained over a series of experiments but not in large numbers. The rest of this work is to consider a large number of experiments with different types of soils ranging from very swelling to sandy clay. Also, for more precision on the values of the vertical transition stresses, other tests in 

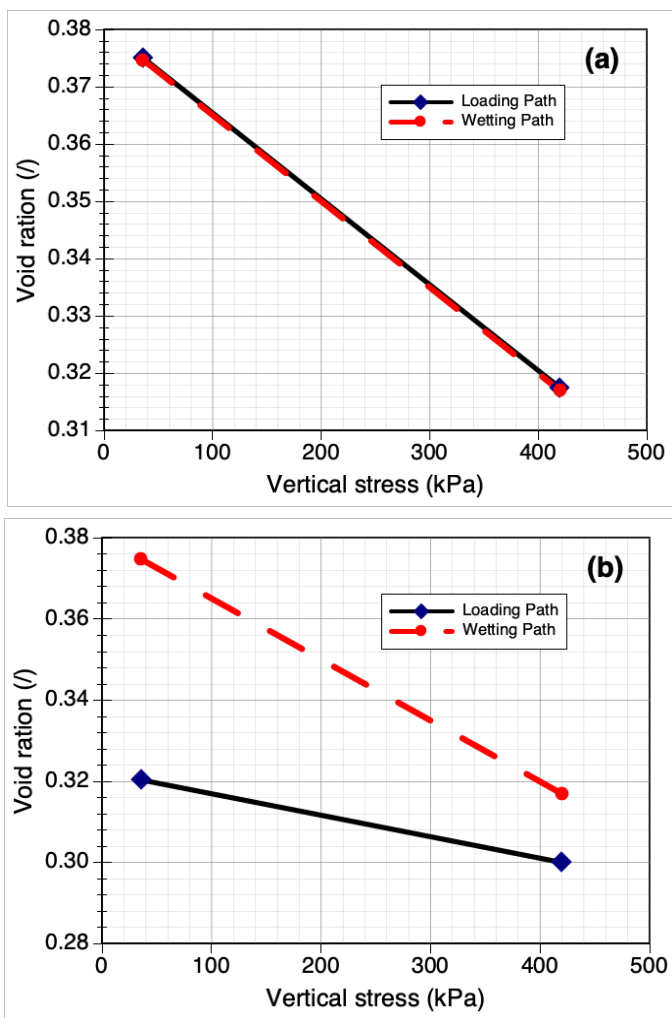

Figure 8. Evolution of void ratio in terms of the vertical stress at mechanical and hydric equilibrium for the NH2 soil: (a) $\rho_{d}=1764 \mathrm{~kg} \cdot \mathrm{m}^{-3}$; (b) $\rho_{d}=1862 \mathrm{~kg} \cdot \mathrm{m}^{-3}$.
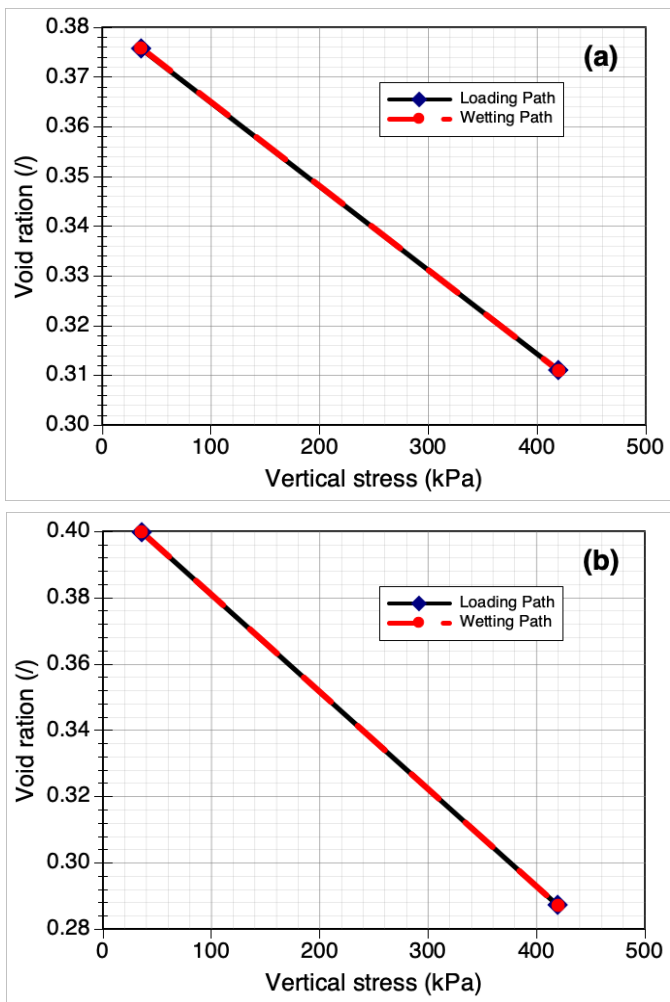

Figure 9. Evolution of void ratio in terms of the vertical stress at mechanical and hydric equilibrium for the NH3 soil: (a) $\rho_{d}=1611 \mathrm{~kg} \cdot \mathrm{m}^{-3}$; (b) $\rho_{d}=1700.5 \mathrm{~kg} \cdot \mathrm{m}^{-3}$. 


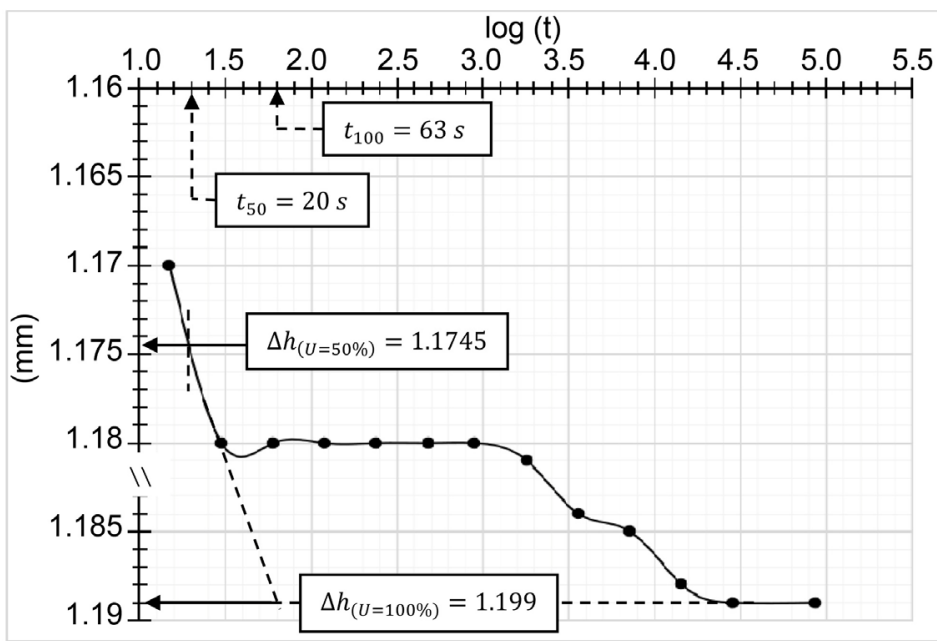

Figure 10. Consolidation curve of the $\mathrm{NH} 2$ soil.

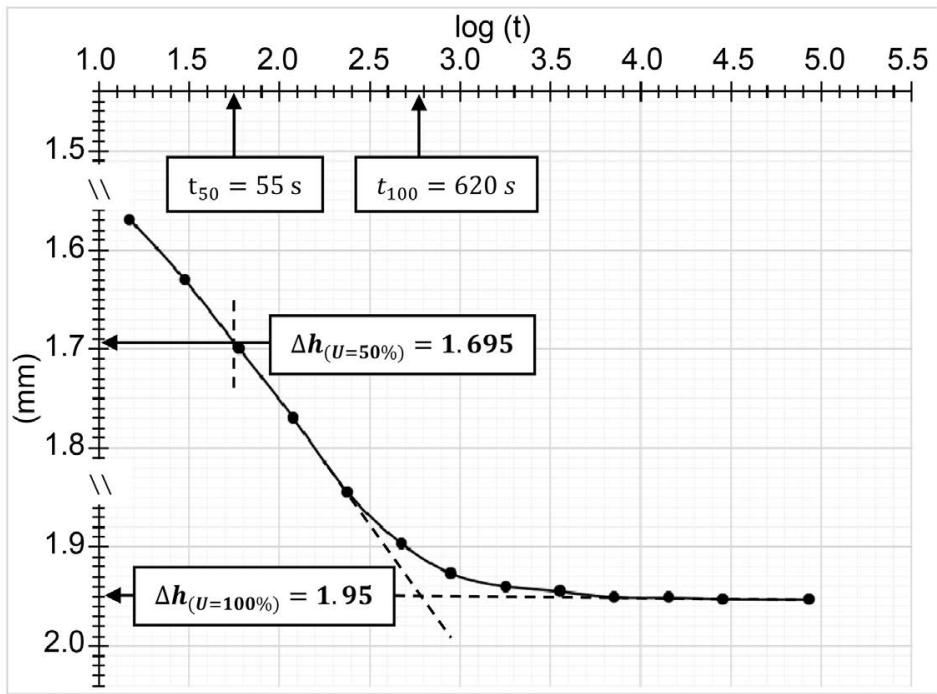

Figure 11. Consolidation curve of the NH3 soil.

Table 8. Vertical transition stress in terms of initial void ratio and dry density.

\begin{tabular}{|c|c|c|c|c|}
\hline \multirow[b]{2}{*}{ Dry density $\rho_{d}\left(\mathrm{~kg} \cdot \mathrm{m}^{-3}\right)$} & \multicolumn{2}{|c|}{$\mathrm{NH} 2$} & \multicolumn{2}{|c|}{ NH3 } \\
\hline & 1764 & 1862 & 1611 & 1700.5 \\
\hline Void ratio $e_{0}(/)$ & 0.363 & 0.329 & 0.404 & 0.414 \\
\hline Transition stress $\sigma_{v t}(\mathrm{kPa})$ & $\sigma_{v t}<36$ & $\sigma_{v t}<36$ & $36<\sigma_{v t}<420$ & $\sigma_{v t}=420$ \\
\hline
\end{tabular}

Table 9. Consolidation characteristics and $E_{\text {oed }}$ and $k_{v}$ of NH2 and NH3 soils.

\begin{tabular}{cccccccc}
\hline & $\Delta h_{(U=100 \%)}$ & $\Delta h_{(U=50 \%)}$ & $t_{100}$ & $t_{50}$ & $E_{\text {oed }}$ & $C_{v}$ & $k_{v}$ \\
\cline { 2 - 7 } & $(\mathrm{mm})$ & $(\mathrm{mm})$ & $(\mathrm{s})$ & $(\mathrm{s})$ & $(\mathrm{Mpa})$ & $\left(\mathrm{m}^{2} \cdot \mathrm{s}^{-1}\right)$ & $\left(\mathrm{m} \cdot \mathrm{s}^{-1}\right)$ \\
\hline $\mathrm{NH} 2$ & 1.199 & 1.174 & 63 & 20 & 7.0 & $9.85 \times 10^{-7}$ & $1.41 \times 10^{-6}$ \\
$\mathrm{NH} 3$ & 1.95 & 1.695 & 620 & 55 & 4.3 & $3.58 \times 10^{-7}$ & $8.31 \times 10^{-7}$ \\
\hline
\end{tabular}


large number to guarantee repeatability can be carried out, also, by adding very deformable soils observed on road works in some areas of Burkina Faso or tropical regions.

\section{Acknowledgements}

This work was carried out within a collaborative framework between University Nazi, Boni of Bobo Dioulasso and the National Laboratory of Public Works of Burkina Faso.

\section{Conflicts of Interest}

The authors declare no conflicts of interest regarding the publication of this paper.

\section{References}

[1] Nguyen Pham, P.T. (2008) Étude en place et au laboratoire du comportement en pétites déformations des sols argileux naturels. Ph.D. Thesis, École Nationale des ponts et chaussées, Paris.

[2] Li, Z.-S., Derfouf, F.-E.M., Benchouk, A., Abou-Bekr, N., Taibi, S. and Fleureau, J.-M. (2018) Volume Change Behavior of Two Compacted Clayey Soils under Hydraulic and Mechanical Loadings. Journal of Geotechnical and Geoenvironmental Engineering, 144, 04018013. https://doi.org/10.1061/(ASCE)GT.1943-5606.0001851

[3] Ahouet, L., Elenga, R.G., Bouyila, S., Ngoulou, M. and Kengue, E. (2018) Amélioration des propriétésgéotechniques de la latérite par ajout de la grave alluvionnaire concassée 0/31, 5. Revue RAMReS-Sci. Appl. \& de P Ing., 3, 1-6.

[4] Kébré, B.M. (2013) Gestion des Ressources en Eau dans les Régions Arides: Analyse Expérimentale d'un Sol Type du Burkina Faso et Modélisation Numérique des Transferts d'Eau. Ph.D. Thesis, Université Montpellier II, France.

[5] Fredlund, M.D., Fredlund, D. and Wilson, G.W. (2000) An Equation to Represent Grain-Size Distribution. Canadian Geotechnical Journal, 37, 817-827.

https://doi.org/10.1139/t00-015

[6] Kébré, M.B., Ouédraogo, F., Betaboalé, N., Zougmoré, F. and Cherblanc, F. (2013) Soil Water Characteristic Curve Modeling at Low Water Content: Empirical and Semi-Empirical Approaches. International Journal of Engineering Research, 2, 432-437.

[7] Kebre, M.B., Cherblanc, F., Ouedraogo, F., Jamin, F., Naon, B., Zougmoré, F. and Benet, J.-C. (2017) Water Flow in Soil at Small Water Contents: A Simple Approach to Estimate the Relative Hydraulic Conductivity in Sandy Soil. European Journal of Soil Science, 68, 167-176. https://doi.org/10.1111/ejss.12408

[8] Durner, W. (1994) Hydraulic Conductivity Estimation for Soils with Heterogeneous Porestructure. Water Resources Research, 30, 211-223.

https://doi.org/10.1029/93WR02676

[9] Ouguemat, A. (2015) Optimisation de la réutilisation de sols de site en remblais d'infrastructures de transports: Effet du compactage à faible teneur en eau. Ph.D. Thesis, Université Mouloud Mammeri Tizi-Ouzou, Algérie.

[10] Magnan, J.P., Mieussens, C., Soyez, B. and Vautrain, J. (1985) Essais œdométriques: Méthodes d'essai LPC ${ }^{\circ} 13$. Laboratoire Central des ponts et Chaussées.

[11] Cuisinier, O. and Masrouri, F. (2003) Comportement hydromécanique d'un sol 
gonflant compacté sous très fortes succions. Comptes Rendus Mécanique, n³31, 203-210. https://doi.org/10.1016/S1631-0721(03)00054-8

[12] Mrad, M., Abdallah, A. and Masrouri, F. (2007) Modélisation numérique du comportement d'un sol gonflant soumis à des variations hydriques. Revue française de géotechnique, $\mathrm{n}^{\circ}$ 120-121, 121-130. https://doi.org/10.1051/geotech/2007120121

[13] Khemissa, M. and Magnan, J.P. (2000) Variabilité des résultats d'essai œedométriques sur l'argile molle de Guiche. Bulletin des Laboratoires des Ponts et Chaussées, 227, 41-50. 